\title{
HUBUNGAN ANTARA TINGKAT STRES BELAJAR DENGAN KECANDUAN GAME ONLINE PADA REMAJA DI SMK NEGERI 2 JEMBER
}

\author{
M. Anugrah Maulana1, Erti I. Dewi ${ }^{2}$, Kholid Rosyidi M. $\mathbf{N}^{3}$ \\ 1,2,3Fakultas Keperawatan Universitas Jember Jl. Kalimantan No. 37 Kampus Tegal Boto Jember \\ e-mail:anugrahmaulana63@gmail.com
}

\begin{abstract}
Abstrak
Perilaku seseorang yang secara terus - menerus untuk bermain game online dapat mengganggu produktivitas remaja seperti menggangu pola tidur, menghabiskan uang saku sekolah, berubahnya emosional yang mengakibatkan peran konflik, membolos sekolah untuk bisa bermain game online. Prevalensi angka kecanduan game online pada remaja dari tahun ke tahun meningkat. Penelitian ini bertujuan untuk menganalisis hubungan antara tingkat stres belajar dengan kecanduan game online. Penelitian ini menggunakan desain analitik observasional dengan pendekatan cross-sectional. Populasi ini menggunakan siswa laki-laki di SMK Negeri 2 Jember berjumlah 2.192, yang kemudian dihitung menggunakan teknik stratified random sampling proporsional (CI: 95\%), dan responden adalah 198. Educational Stress Scale Adolescent (ESSA) menggunakan skala likert dengan nilai reliabilitas a $=0,785$ ditemukan 16 item valid. Kuesioner Indonesian Online Game Addiction Questionnaire menggunakan skala likert dengan nilai reliabilitas a $=0,73$ ditemukan 7 item valid. Analisis data yang digunakan adalah tes Spearman (CI: 95\%). Korelasi antara tingkat stres belajar dengan kecanduan game online ( $p=0,000$; $a<0,05$ dan $r=0,283$ ), Stres belajar berhubungan dengan kecanduan game online karena tujuan remaja bermain game online agar melarikan diri dari masalah seperti tuntutan belajar yang dinilai berat, bosan dalam belajar dan tugas yang banyak dapat menyebabkan stres belajar. Sebagai perawat komunitas harus dapat meningkatkan upaya promotif dan preventif mengenai dampak dari kecanduan game online serta cara pencegahannya agar para remaja yang mengalami stress belajar dapat meminimalisir resiko kecanduan game online.
\end{abstract}

Kata kunci: Stres Belajar, Kecanduan Game Online, Remaja

\begin{abstract}
The human behaviour keeping eager to playing online games can disturbing adolescence productivity as a disturbed sleeping pattern, spending the money for the school, changing the emotions can affect conflict roles for playing online games. The addiction of online games year by year keeping higher. The research goal is to analyze the correlation between stress level of learning and online game addiction. This research used an observational with a Cross-sectional approach. The male population in SMK Negeri 2 Jember is 2.192, which was then calculated using the proportionate stratified random sampling technique (CI: 95\%), and respondents were 198. Educational Stress Scale Adolescent (ESSA) using a likert scale with reliability value a=0.785 found 16 items valid. Indonesian Online Game Addiction Questionnaire using a likert scale
\end{abstract}


M. Anugrah Maulana, Erti I. Dewi, dan Kholid Rosyidi, Hubungan antara Tingkat Stres Belajar dengan Kecanduan Game Online pada Remaja di SMK Negeri 2 Jember

with reliability value $a=0.73$ found 7 items valid. The data analysis used is the Spearman test (CI:95\%). The correlation between stress level of learning with online game addiction ( $p=0.000 ; a<0.05$ and $r=0.283$ ), study stress-related with online game addiction because the aim of adolescents to playing games is for running away for the study pressure and viewed as hard things, worrying and more got stressed. As community nurse should to improving promotive and preventive action due the effect of the addiction online games with the prevention to minimalize the study stress and to decrease the online game's addiction in adolescents.

Keywords: Study Stress, Addiction Game Online, Adolescent

\section{PENDAHULUAN}

Karakteristik dari remaja adalah keingintahuannya yang tinggi dengan mencoba hal-hal baru seperti bermain game online. Usia remaja sangat mudah dipengaruhi oleh teman sebaya yang keinginannya ikut-ikut dengan mengakibatkan masalah, misalnya mengalami kecanduan game online (Wulan, 2012). Perilaku seseorang yang selalu bermain game online yang lupa dengan waktu dapat menggangu produktifitas pada remaja seperti mengganggu pola tidur, menghabiskan uang saku sekolah untuk kebutuhan bermain game online, berubahnya emosional yang mengakibatkan peran konflik yang mengakibatkan remaja kecanduan game online (Nurazmi, 2018). Menurut International Classification of Diseases (ICD-11) dalam WHO (2018), kecanduan game online adalah gangguan pola perilaku pemain game online yang ditandai dengan gangguan mental dan lebih memprioritaskan bermain game online dari kegiatan lain dalam sehari-hari. Negara-negara telah mengakui kecanduan game online termasuk suatu masalah kesehatan yang harus segera ditangani atau dicegah (WHO, 2018).

Dinyatakan bahwa seseoarang yang mengalami kecanduan game online bermain selama 4 sampai 5 hari dalam seminggu, jika seseorang dinyatakan kecanduan game online berat seseorang akan dapat menghabiskan bermain game online sekitar 7 sampai 8 jam atau lebih sehingga menggangu pola tidurnya (Jap dkk., 2013). Industri game online yang semakin berkembang menjadikan fitur dan teknologinya semakin portable sehingga game online bisa diakses dimana saja dan kapan saja (Nurdila, 2018).

Menurut Jap dkk (2013) prevalensi 
kecanduan game online pada tahun 2012 ditemukan dari 3.264 siswa remaja. Menurut Piyeke (2014) menunjukan pada tahun 2012 data jumlah pengguna internet sebanyak 62 juta orang di Indonesia di semua kalangan usia. Pengguna internet pada tahun 2013 meningkat secara signifikan sejumlah 74,5 juta orang. Penggunaan internet lebih banyak digunakan remaja untuk bermain game online. Menurut Nurazmi (2017) jumlah siswa yang diteliti 267 responden pada laki-laki sejumlah 235 (88\%) dan perempuan $32(12 \%)$ berdasarkan lama bermain yaitu rentang waktu 7-9 jam/hari dengan jumlah 96 responden (36\%). Hasil remaja yang positif kecanduan berjumlah 107 orang responden $(40,1 \%)$ (Nurazmi, 2017). Data dari Asosiasi Penyelanggara Jasa Internet Indonesia (APJII) (2017) yang menjelaskan bahwa di Indonesia besar pengguna internet yaitu laki- laki sejumlah 51,43\%.

Remaja yang mengalami tuntutan belajar yang dinilai berat, hasil nilai turun, kompetisi dalam prestasi, bosan dalam belajar dan tugas yang banyak yang dapat menyebabkan stres belajar (Wulandari, 2015). Prevalensi siswa yang terbebani dengan keharusan mempertahankan peringkat nilai disekolah sekitar 40,74\%, siswa mengalami kecemasan saat melakukan ujian semester sekitar $62,96 \%$, siswa merasa kebingungan terhadap mengerjakan pekerjaan rumah (PR) sangat banyak $82,72 \%$ dan pemberian materi yang diberikan didalam kelas dengan waktu yang lama adalah 50,62\% (Barseli dkk., 2017). Organization For Economic Co-Operation And Development (OECD) melakukan survei melibatkan 72 negara dan terdiri dari 540.000 responden pelajar berusia 15-16 tahun. Di rata-rata negara $66 \%$ siswa melaporkan merasa tertekan terhadap nilai yang buruk dan $59 \%$ sering khawatir bahwa berfikiran ujian akan sulit. 55\% Siswa merasa sangat cemas tentang ujian bahkan mereka tidak siap melakukan ujian. Siswa melaporkan merasa tegang saat belajar sebanyak 37\% (Abebe dkk, 2018). Sehingga penggunaan internet dari tahun ketahun meningkat secara signifikan pada remaja.

Setelah dilakukan studi pendahuluan pada tanggal 5 November 2019 di SMK Negeri 2 Jember didapatkan informasi bahwa siswa kelas XI tidak dapat dijadikan responden 
M. Anugrah Maulana, Erti I. Dewi, dan Kholid Rosyidi, Hubungan antara Tingkat Stres Belajar dengan Kecanduan Game Online pada Remaja di SMK Negeri 2 Jember

dikarenakan selama 6 bulan kedepan dimulai dengan bulan Januari sampai Juni melakukan Pelatihan Kerja Lapang (PKL). Maka dari itu peneliti mengambil responden siswa laki-laki dari kelas X dan XII. Mata pelajaran yang ditempuh dari mata kuliah wajib dan advokasi.

Terdapat siswa bermain handphone saat pelajaran dan saat jam istirahat banyak siswa bermain game online. Menurut data Dapodik (2019) yakni detail sekolah berdasarkan kemendikbud terdapat jumlah populasi remaja di SMK Negeri 2 Jember untuk siswa laki-laki kelas X dan XII adalah 1413 orang. Peneliti melaksanakan di SMK Negeri 2 Jember karena jumlah siswa laki-laki yang paling banyak di SMK Negeri 2 Jember dan angka kejadian kecanduan terhadap game online kebanyakan dalam usia remaja.

Penjelasan diatas menjadikan alasan seorang remaja dapat kecanduan game online karena adanya tekanan dari proses belajar yang dapat menimbulkan stres yang nantinya akan menjadikan bermain game online sebagai jalan keluar untuk menghadapinya. Maka peneliti mengambil judul tersebut untuk mengetahui apakah ada hubungan antara kedua variabel.

\section{METODE PENELITIAN}

Jenis penelitian menggunakan observasional analitik dengan pendekatan Cross Sectional (Masturoh \& Anggita, 2018). Siswa laki-laki di SMKN 2 Jember adalah sebagai responden. Menurut data Dapodik (2019) di SMKN 2 Jember untuk jumlah laki-laki dikelas X dan XII sejumlah 1413 siswa, untuk kelas XI tidak dapat menjadi responden dikarenakan ada praktek kerja lapangan (PKL) yang harus diikuti oleh siswa kelas XI, yang seharusnya juga menjadi responden penelitian.

Teknik perhitungan yang digunakan yaitu proportionate stratified random sampling didapatkan 180. Menurut Sastroasmoro (2014) untuk mengatasi adanya drop out, pada sampel ditambahkan sebesar 10\%, yakni sebanyak 18 . Sehingga jumlah sampel didapatkan adalah 180 $+18=198$ responden. Untuk mencapai sampel, setiap populasi diseleksi secara acak sehingga mencapai responden yang dibutuhkan sesuai rumus proportionate stratified random sampling. Selanjutnya sampel dipilih secara acak menggunakan www.randomization.com. Peneliti membagikan informed consent dan 
kuesioner kepada responden. Uji etik penelitian dilakukan di Fakultas Kedokteran Gigi, Universitas Jember, dengan nomor: No. 747 /UN25.8 / KEPK / DL / 2019.

Analisis univariat merupakan suatu proses pengolahan data yang digunakan dengan tujuan untuk mendiskripsikan suatu variabel (Notoatmodjo, 2012). Analisis univariat merupakan analisis deskriptif dengan hasil pengolahan datanya berupa gambaran data dalam bentuk tabel ataupun grafik secara ilmiah (Nursalam, 2017). Analisis bivariat dalam penelitian ini untuk mengetahui hubungan antara tingkat stres belajar dengan kecnduan game online pada remaja di SMKN 2 Jember. Skala pengukuran dari variabel stres belajar dan kecanduan game online berbentuk kategorik ordinal-ordinal dengan uji statistik yaitu spearman yang dapat mengetahui arah hubungan, kekuatan korelasi dan hubungan antara kedua variabel.

\section{HASIL PENELITIAN}

\section{Karakteristik Responden}

Berdasarkan data pada kuesioner, diperoleh hasil sebagai berikut
Tabel 1

Distribusi responden pada laki-laki di SMK Negeri 2 Jember

\begin{tabular}{|c|c|c|}
\hline Variabel & Jumlah & Persentase $(\%)$ \\
\hline \multicolumn{3}{|l|}{ Usia (Tahun) } \\
\hline \multicolumn{3}{|c|}{$($ Median $=17 ; \operatorname{Min}=14 ; \operatorname{Max}=19)$} \\
\hline \multicolumn{3}{|l|}{ Uang saku perminggu } \\
\hline Kurang dari Rp. 20 ribu & 8 & 4,0 \\
\hline Rp. 20 ribu- Rp. 50 ribu & 29 & 14,6 \\
\hline Rp. 50 ribu- Rp. 100 ribu & 101 & 51,0 \\
\hline Rp. 100 ribu-Rp. 200 ribu & 55 & 27,8 \\
\hline Rp. 200 ribu-Rp. 300 ribu & 4 & 2,0 \\
\hline Lebih dari Rp. 300 ribu & 1 & 0,5 \\
\hline Total & 198 & 100,0 \\
\hline \multicolumn{3}{|c|}{ Habis uang bulanan untuk bermain game } \\
\hline Kurang dari Rp. 20 ribu & 5 & 2,5 \\
\hline Rp. 20 ribu - Rp. 50 ribu & 75 & 37,9 \\
\hline Rp. 50 ribu- Rp. 100 ribu & 82 & 41,4 \\
\hline Rp. 100 ribu - Rp 200 ribu & 25 & 12,6 \\
\hline Rp. 200 ribu - Rp. 300 ribu & 7 & 3,5 \\
\hline Lebih dari Rp. 300 ribu & 4 & 2,0 \\
\hline Total & 198 & 100,0 \\
\hline \multicolumn{3}{|l|}{ Penghasilan orang tua/ wali } \\
\hline Kurang dari Rp. 500 ribu & 9 & 4,5 \\
\hline Rp. 500 ribu - Rp. 1 juta & 66 & 33,3 \\
\hline Rp. 1 juta - Rp. 2 juta & 69 & 34,8 \\
\hline Rp. 2 juta -Rp. 3 juta & 26 & 13,1 \\
\hline Lebih dari Rp. 3 juta & 28 & 14,1 \\
\hline Total & 198 & 100,0 \\
\hline
\end{tabular}

Waktu harian bermain game online dalam satu minggu

$\begin{array}{ccc}\text { 2-3 hari/ minggu } & 60 & 30,3 \\ 4-5 \text { hari/ minggu } & 87 & 43,9 \\ 6-7 \text { hari/ minggu } & 51 & 25,8 \\ \text { Total } & 198 & 100,0\end{array}$

\begin{tabular}{lcc}
\hline Jam bermain game online dalam sehari & \\
$0-1 / 2$ jam/hari & 3 & 1,5 \\
, $1 / 2$ jam -1 jam/hari & 26 & 13,1 \\
, 2 jam - 3 jam/hari & 48 & 24,2 \\
, 3 jam - 4 jam/hari & 43 & 21,7 \\
, 4 jam - 5 jam/hari & 54 & 27,3 \\
, 5 jam - 6 jam/hari & 10 & 5,1 \\
, 6 jam - 7 jam/hari & 4 & 2,0 \\
, 7 jam/hari & 10 & 5,1 \\
Total & 198 & 100,0 \\
\hline
\end{tabular}

Berdasarkan tabel 1 Usia responden yaitu 17 tahun, dengan minimal usia 14 dan maksimal usia responden 19 tahun. Uang saku 
M. Anugrah Maulana, Erti I. Dewi, dan Kholid Rosyidi, Hubungan antara Tingkat Stres Belajar dengan Kecanduan Game Online pada Remaja di SMK Negeri 2 Jember

perminggu paling banyak pada Rp. 50 ribu Rp. 100 ribu dengan jumlah siswa 101 siswa $(51,0 \%)$ dan hasil yang menjawab lebih dari Rp.300 ribu perminggu dengan jumlah 1 siswa $(0,5 \%)$. Habis uang bulanan untuk bermain game paling banyak adalah Rp. 50 ribu - Rp. 100 ribu dengan jumlah 82 siswa $(41,4 \%)$ dan hasil yang menjawab lebih dari Rp.300 ribu dengan jumlah 4 siswa $(2,0 \%)$. Untuk penghasilan orang tua/wali paling banyak adalah Rp. 1 juta - Rp. 2 juta dengan jumlah 69 siswa $(34,8 \%)$ dan penghasilan orang tua adalah kurang dari Rp. 500 ribu sejumlah 9 siswa $(4,5 \%)$. Waktu game harian bermain game online dalam satu minggu paling banyak 4-5 hari/ minggu dengan jumlah 87 siswa (43,9\%) dan yang menjawab 6-7 hari/ minggu dengan jumlah 51 siswa $(25,8 \%)$. Dan untuk rata-rata jam bermain game online dalam sehari paling banyak adalah 4-5 jam/ hari dengan jumlah siswa 54 siswa $(27,3 \%)$, yang menjawab $0-1 / 2$ jam/hari sejumlah 3 siswa $(1,5 \%)$

\section{Kecanduan Game Online}

Tabel 2

Nilai rerata kecanduan game online pada remaja laki-laki di SMK Negeri 2 Jember

\begin{tabular}{crc}
\hline Variabel & Median & Min-Max \\
\hline Kecanduan Game Online & 16,00 & $14-35$ \\
\hline
\end{tabular}

Berdasarkan uji normalitas Kolmogorov-

Smirnov dihasilkan $\mathrm{p}=0,000$, sehingga dikatakan berdistribusi tidak normal. Sehingga didapatkan hasil nilai tengah pada variabel kecanduan game online adalah 16,00 dengan nilai minimal 14 dan maksimal 35.

Tabel 3

Distribusi kecanduan game online pada siswa laki-laki di SMK Negeri 2 Jember

\begin{tabular}{lcc}
\hline \multicolumn{1}{c}{ Variabel } & Jumlah & Persentase (\%) \\
\hline $\begin{array}{l}\text { Kecanduan } \\
\text { game ontine }\end{array}$ & & \\
$\begin{array}{l}\text { Kecanduan game } \\
\text { online ringan }\end{array}$ & 165 & 83,3 \\
$\begin{array}{l}\text { Kecanduan game } \\
\text { online berat }\end{array}$ & 33 & 16,7 \\
\hline \multicolumn{1}{c}{ Totat } & 198 & 100,0 \\
\hline
\end{tabular}

Berdasarkan tabel 3 didapatkan hasil bahwa pada siswa laki-laki di SMK Negeri 2 Jember sebanyak 165 siswa $(83,3 \%)$ dengan kategori kecanduan game online ringan. Kemudian kategori kecanduan game online berat dengan jumlah 33 siswa (16,7\%). Menurut Jap dkk (2013) untuk skor 14 - 21 
dinyatakan dalam kecanduan ringan dan skor lebih dari 21 dinyatakan dalam kecanduan berat dengan menggunakan kuesioner Indonesian Online Game Addiction Questionnaire. Skor $7-13$ dinyatakan tidak mengalami kecanduan game online. Dalam hasil ini tujuannya tidak untuk diagnostik klinis seperti mental klinis, hanya untuk skrining awal kepada siswa laki-laki di SMK Negeri 2 Jember.

\section{Stres Belajar}

Hasil penelitian tentang variabel stres belajar dapat dilihat pada tabel 4 berikut.

Tabel 4

Nilai rerata stres belajar pada siswa laki-laki di SMK Negeri 2 Jember

\begin{tabular}{ccc}
\hline Variabel & Median & Min-Max \\
\hline Stres Belajar & 50,50 & $28-72$ \\
\hline Berdasarkan & uji & normalitas
\end{tabular}

Kolmogorov-Smirnov dihasilkan p $=0,001$, sehingga dikatakan berdistribusi tidak normal. Dikatakan berdistribusi normal apabila $\mathrm{p}>$ 0,05. Sehingga didapatkan hasil nilai tengah pada variabel stress belajar adalah 50,50 dengan nilai minimal 28 dan maksimal 72.
Tabel 5

Distribusi tingkat stress belajar pada siswa laki-laki di SMK Negeri 2 Jember

\begin{tabular}{lcc}
\hline Variabel & Jumlah & Persentase (\%) \\
\hline Tingkat stres belajar & & \\
a. Stres belajar rendah & 10 & 5,1 \\
b. Stres belajar sedang & 177 & 89,4 \\
c. Stres belajar tinggi & 11 & 5,6 \\
\hline Total & 198 & 100,0 \\
\hline
\end{tabular}

Berdasarkan tabel 5 didapatkan hasil bahwa pada siswa laki-laki di SMK Negeri 2 Jember sebanyak 177 siswa $(89,4 \%)$ pada kategori tingkat stres belajar sedang. Menurut Sun (2011) dengan menggunakan kuesioner Educational Stres Scale Adolescent (ESSA) yang terdiri dari 16 pertanyaan dengan $1-5$ likert, yang intrepetasi hasil menggunakan menurut Azwar (2009) yang didapatkan hasil x $<37$ dinyatakan stress belajar rendah, $37 \leq \mathrm{x}<$ 59 dinyatakan stress belajar sedang, $59 \leq x$ dinyatakan stress belajar tinggi.

\section{Hubungan antara Tingkat Stres Belajar dengan Kecanduan Game Online pada \\ Remaja di SMK Negeri 2 Jember \\ Tabel 6}

Analisa hubungan antara tingkat stres belajar dengan kecanduan game online pada remaja di SMK Negeri 2 Jember

\begin{tabular}{ccc}
\hline Variabel & & \multicolumn{1}{c}{ Kecanduan Game Online } \\
\hline \multirow{2}{*}{ Stres Belajar } & $\mathrm{r}$ & 0,283 \\
\cline { 2 - 3 } & $\mathrm{p}$ value & 0,000 \\
\cline { 2 - 3 } & $\mathrm{n}$ & 198 \\
\hline
\end{tabular}


M. Anugrah Maulana, Erti I. Dewi, dan Kholid Rosyidi, Hubungan antara Tingkat Stres Belajar dengan Kecanduan Game Online pada Remaja di SMK Negeri 2 Jember

Berdasarkan uji statistik spearman didapatkan nilai Sig. (2-tailed) sebesar 0,000 yang artinya nilai signifikansi $<\alpha(\alpha=0,05)$, jadi kedua variabel saling berhubungan.

Berdasarkan hasil analisis tersebut dapat diketahui juga nilai koefisien korelasi (correlation coefficient) sebesar 0,283 yang berarti menunjukkan bahwa kekuatan hubungan yang rendah pada kedua variabel tersebut. Hubungan antara stress belajar dengan kecanduan game online berkorelasi positif yang berarti ketika stres belajar tinggi maka kecanduan game online tinggi.

\section{PEMBAHASAN}

\section{Karakteristik responden}

a. Usia

Pengambilan sampel oleh peneliti adalah pada usia 14-19 tahun. Kebanyakan usia pada penelitian ini berumur 17 tahun. Hasil penelitian lain juga menyebutkan bahwa mayoritas yang kecanduan game online adalah remaja berusia $15-18$ tahun sejumlah 27 siswa (45\%) (Rahmat, 2014). Hasil penelitian lain menyebutkan bahwa usia rata - rata kecanduan game online 16,7 tahun dengan remaja laki - laki sejumlah 122 orang $(97,54 \%) \quad$ (Rahmadina, 2014). Menurut peneliti, usia remaja sangat dipengaruhi oleh pergaulan teman sebaya yang rentan terhadap kecanduan game online.

b. Uang saku perminggu

Hasil penelitian menunjukkan bahwa uang saku perminggu paling banyak adalah $\mathrm{Rp}$. 50 ribu - Rp. 100 ribu dengan jumlah 101 siswa $(51,0 \%)$. Hasil penelitian lain di SMA Negeri 5 Surakarta pada bulan April 2018 pada uang saku perharinya melebihi Rp. 10 ribu atau dalam seminggu bisa mencapai Rp. $50-$ Rp. 100 ribu sebesar $81,3 \%$ responden (Cahyaningtyas, 2018). Uang saku siswa nantinya terbagi untuk bermain game online (membeli kuota internet atau pergi ke game center) dan untuk membeli makanan atau minuman, sehingga uang yang seharusnya untuk membeli makan dan minuman jadi berkurang oleh kebutuhan game online.

c. Uang bulanan untuk bermain game

Hasil penelitian menunjukkan bahwa uang bulanan untuk bermain game paling banyak adalah Rp. 50 ribu - Rp. 100 ribu dengan jumlah 82 siswa $(41,4 \%)$. Hasil 
penelitian lain juga menghasilkan bahwa remaja mengeluarkan biaya sebesar Rp. 50 ribu - Rp. 100 ribu dengan jumlah 18 responden $(60 \%)$ untuk bermain game (Suryanto, 2015).

d. Penghasilan orang tua/ wali

Hasil menunjukkan bahwa penghasilan orang tua/ wali paling banyak adalah Rp. $1.000 .000,00$ sampai Rp. 2.000,000,00 dengan jumlah 69 siswa (34,8\%). Pendapatan orang tua berhubungan dengan kecanduan game online hal ini disebabkan karena remaja akan meminta kepada orang tuanya melebihi kapasitas yang diberikan karena merasa kekurangan uang saku berbagai alasan seperti untuk mengerjakan tugas di sekolah, sehingga memperburuk ekonomi keluarga (Susanto, 2010).

e. Waktu harian bermain game online dalam satu minggu

Hasil penelitian menunjukkan bahwa bermain game online harian dalam seminggu, responden paling banyak menjawab adalah 4 sampai 5 hari/minggu untuk bermain game online dengan jumlah 87 orang (43,9\%). Dalam penelitian lain menunjukkan bahwa dalam seminggu dapat bermain hingga 4-5 hari/ perminggu dengan jumlah 210 responden $(14,20 \%)$ (Jap dkk, 2013). Bermain game online pada remaja selama seminggu bisa mencapai 4-5 hari/ perminggu yang dapat dinyatakan bahwa seseorang mengalami kecanduan game online. Menurut peneliti, remaja yang sudah kecanduan game online akan menghabiskan waktunya dan terbuang sia-sia sehingga melupakan aktifitas seharihari untuk bermain game online.

f. Bermain game online jam dalam sehari Hasil menunjukkan bahwa dalam sehari paling banyak yaitu 4- 5 jam/ hari dengan jumlah 54 orang $(27,3 \%)$ untuk bermain game online. Hasil penelitian lain juga menunjukkan 4- 6 jam /hari dengan jumlah 16 orang (53\%) (Suryanto, 2015). Penelitian lain menunjukkan bahwa 4 - 5 jam dengan jumlah 128 responden (8,7\%) (Jap dkk, 2013). Bermain game online normalnya yaitu kurang dari 3 jam perhari, dari hasil penelitian menunjukkan 4-5 hari yang dinyatakan bahwa remaja termasuk kedalam kecanduan game online. Menurut peneliti, jika seseorang sudah kecanduan game pada remaja akan 
M. Anugrah Maulana, Erti I. Dewi, dan Kholid Rosyidi, Hubungan antara Tingkat Stres Belajar dengan Kecanduan Game Online pada Remaja di SMK Negeri 2 Jember

memikirkan game secara terus menerus sehingga akan menambah waktu bermain game itu terus perharinya dari $4-5$ jam dapat bertambah karena dengan asiknya bermain.

\section{Kecanduan game online}

Hasil penelitian menyebutkan bahwa pada remaja laki-laki di SMK Negeri 2 Jember lebih banyak didapatkan kecanduan game online rendah dengan jumlah 165 (83,3\%) dalam hasil ini tujuannya tidak untuk diagnostik klinis seperti mental klinis, hanya untuk skrining awal kepada siswa laki-laki di SMK Negeri 2 Jember. Hasil penelitian lain yaitu untuk kecanduan game online berat pada penelitiannya didapatkan sebanyak 44 orang $(27,2 \%)$ dan kecanduan game online ringan yaitu sejumlah 118 (72,8\%) (Mulyaningsih, 2019). Remaja dapat mengalami kecanduan karena sifat game untuk membuat pemain tertarik hingga tidak dapat berhenti. Hal lainnya yaitu melupakan kegiatan sehari - hari atau tugas dari sekolah, kurangnya sosialisasi yang didapat dari lingkungan dan lupa akan waktu (Ridwan, 2015). Kecanduan game online terindikasi rendah karena masih bertujuan untuk menghilangkan jenuh dalam kegiatan sehari - hari (Masya, 2016).

SMK Negeri 2 Jember telah melarang siswanya tidak membawa smartphone ke sekolah karena akan mengganggu kegiatan disekolah tetapi beberapa siswa masih saja ada yang membawa smartphone yang membuat angka kecanduan remaja laki-laki di SMK 2 Negeri Jember berindikaktor kecanduan game online rendah.

\section{Indikator Instrument Kecanduan Game \\ Online}

Dalam instrumen yang digunakan oleh peneliti yaitu menggunakan Indonesian Online Game Addiction Questionnaire dengan 5 indikator yaitu peran konflik, pemikiran tentang game online setiap hari, toleransi penggunaan game online, menekankan penggunaan game online sebagai media melarikan diri dari masalah, peran orang lain untuk mencegah kecanduan, efek penarikan tidak bermain game online, kekurangan untuk tidur. Konflik dalam kecanduan game online dihubungkan dengan kondisi konflik dengan diri sendiri, dengan keluarga maupun dengan teman. Konflik diri sendiri dapat terjadi karena 
kesulitan untuk berinteraksi dengan orang lain secara langsung (Taylor dkk, 2017).

Penelitian ini juga mengidentifikasi bahwa indikator pemikiran bermain game online, karena remaja menyukai game online adalah faktor rasa kebebasan, kenyamanan, dan rekreasi yang menimbulkan keasyikaan saat bermain game online dengan waktu yang lama (Lee dkk, 2016).

Indikator lainnya yaitu kurangnya tidur pada remaja karena aktifitas yang berlebihan saat bermain game online. Menurut Septiana dkk (2018) mengatakan bahwa seseorang yang kekurangan tidur akan berdampak pada fisik seseorang yang mengakibatkan kelelahan yang menurunkan aktifitas fisik.

Indikator selajutnya yaitu mengenai toleransi terhadap waktu, hal ini disebabkan remaja yang merasa keasyikan dalam bermain game akan cenderung menambah waktu untuk bermain game sebagai median kompensasi perasaan yang tidak diinginkan.

Indikator lainnya yaitu efek penarikan tidak bermain game online, menurut Griffiths dkk (2016) yang meneliti mengenai pengalaman subyektif remaja sebagai konsekuensi dari penggunaan internet atau bermain game online akan mengakibatkan gangguan perasaan pemain. Remaja mengalami perasaan bahagia saat bermain game ditandai dengan meningkatnya durasi bermain game online. Sehingga membuat hubungan antara teman dan keluarga menjadi renggang karena selalu bermain game online.

Indikator melarikan diri dari masalah dalam penelitian yang dilakukan oleh Pang dkk (2017) menyebutkan bahwa salah satu motivasi yang menyebabkan remaja cenderung bermain game online yaitu melarikan diri dari kehidupan nyata dan menghindari masalah di kehidupan nyata.

\section{Tingkat stres belajar}

Hasil penelitian menyebutkan bahwa pada remaja laki-laki di SMK Negeri 2 Jember lebih banyak stres belajar sedang dengan jumlah 177 siswa $(89,4 \%)$. Hasil penelitian lain yaitu untuk stres belajar di SMAN Se-Kota Malang didapatkan dengan 256 responden $(70,33 \%)$ dalam kategori stres belajar sedang (Abrianti, 2012). Menurut Thursan (2005) pembelajaran dengan materi yang sulit dapat menyebabkan siswa merasa 
M. Anugrah Maulana, Erti I. Dewi, dan Kholid Rosyidi, Hubungan antara Tingkat Stres Belajar dengan Kecanduan Game Online pada Remaja di SMK Negeri 2 Jember

takut terhadap guru yang mengajar sehingga dapat disebut juga stres belajar. Menurut peneliti, Stres belajar sangat berpengaruh dalam keadaan berfikir remaja laki-laki yang menyebabkan tidak konsentrasi dalam belajar.

\section{Indikator Instrument Tingkat Stres Belajar}

Dalam instrumen yang digunakan oleh peneliti yaitu menggunakan Educational Stres Scale Adolescent (ESSA) dengan 5 indikator yang mengidentifikasi terjadinya stress belajar. Salah satu indikatornya yaitu tekanan dari belajar, menurut Azis (2017) beban psikologis karena dari proses belajar yang dapat mengakibatkan stress pada seseorang.

Indikator selanjutnya yaitu beban tugas, menurut Rahmawati (2016) Stres belajar diakibatkan oleh pikiran negatif siswa terhadap tuntutan atau tekanan dalam belajar. Tugas akademik yang dianggap sebagai beban atau tekanan yang membuat munculnya pikiran negatif bagi siswa. Apabila pikiran negatif tersebut dibiarkan akan menyebabkan terganggunya proses belajar mengajar didalam sekolah atau diluar sekolah. Tugas yang banyak menjadikan siswa mengalami stres belajar dan berakibat pada menurunnya kualitas belajar.

Indikator berikutnya yaitu khawatir tentang hasil nilai, menurut Safitri (2019) Tingkat khawatir tentang nilai yang tinggi dapat menurunkan prestasi akademik. Tingginya kekhawatiran pada siswa menimbulkan kesulitan baginya untuk berkonsentrasi.

Indikator selanjutnya kesedihan, dimana pada masa ini menentukan masa depan untuk menyelesaikan dengan baik mengenai akdemik yang membuat keluarga menaruh harapan tinggi untuk kedepannya. Sehingga siswa kurang percaya diri jika hasil yang sudah dilakukan sesuai standartnya tidak menghasilkan nilai yang bagus yang membuat siswa stres.

Indikator yang terakhir harapan diri, Berdasarkan penelitian Ang dan Huan (2007) terdapat dua dimensi terkait harapan akademik, yaitu harapan orang tua dan guru dan harapan diri sendiri. Pertama, mahasiswa sering mendapat tekanan dari guru dan orang tua untuk mencapai dan mempertahankan prestasi yang baik. Keunggulan akademik sangat 
ditekankan bagi mahasiswa untuk berjuang mencapai tempat tertinggi. Kedua, mahasiswa mengalami tekanan internal karena memiliki motivasi diri yang kuat untuk dapat unggul dalam akademik. Pernyataan ini sejalan dengan temuan Tan dan Yates (2011) yang menyatakan bahwa harapan akademik baik dari orang tua dan dosen maupun dari diri sendiri berpengaruh terhadap tingkat stres belajar seseorang.

Hubungan antara Tingkat Stres Belajar dengan Kecanduan Game Online pada Remaja di SMK Negeri 2 Jember

Hasil penelitian yang dilakukan oleh peneliti didapatkan adanya hubungan antara tingkat stres belajar dengan kecanduan game online pada remaja di SMK Negeri 2 Jember dan memiliki korelasi arah positif dimana semakin tinggi tingkat stres belajar, semakin tinggi pula kecanduan game online dengan kekuatan korelasi rendah. kelas XI tidak dapat menjadi responden dikarenakan ada praktek kerja lapangan (PKL) yang harus diikuti oleh siswa kelas XI, yang seharusnya juga menjadi responden penelitian. Hubungan yang diperoleh dalam penelitian ini antara tingkat stress belajar dengan kecanduan game online menunjukkan bahwa stres belajar adalah salah satu faktor yang membuat seseorang mengalami kecanduan game online.

\section{SIMPULAN}

Kecanduan game online pada remaja di SMK Negeri 2 Jember lebih banyak didapatkan kecanduan game online rendah $(83,3 \%)$. Tingkat stres belajar pada remaja lebih banyak didapatkan stres belajar sedang $(89,4 \%)$. Terdapat hubungan antara kedua variabel yang menunjukkan hasil hubungan yang arah positif dan mempunyai kekuatan hubungan yang rendah.

\section{SARAN}

Dapat dilakukan konsultasi secara bergilir, terlebih pada siswa yang diketahui memiliki tingkat kecanduan game online. Konsultasi bisa dengan mendatangkan tenaga kesehatan/ peran puskesmas dalam program UKS. 
M. Anugrah Maulana, Erti I. Dewi, dan Kholid Rosyidi, Hubungan antara Tingkat Stres Belajar dengan Kecanduan Game Online pada Remaja di SMK Negeri 2 Jember

\section{DAFTAR PUSTAKA}

Abebe, A. M., Y. G. Kebede, \& F. Mengistu. (2018). Prevalence of stress and associated factors among regular students at debre birhan governmental and non governmental health science colleges north showa zone, amhara region, ethiopia 2016. 2018

Abrianti, R. S. (2012). Perbedaan Tingkat Stres Belajar Siswa Full Day Scholl dan Siswa Reguler SMAN Se-Kota Malang.

Ang, R.P. Huan, V.S. \& Braman OR. (2007). Factorial Structure and Invariance of the Academic Expectations Stress Inventory Across Hispanic and Chinese Adolescent Samples. Child Psychiatry Hum Dev, Vol. 38, Hal. 73-87.

Asosiasi Penyelenggara Jasa Internet Indonesia (APJII). (2017). Penetrasi dan perilaku pengguna internet indonesia. Diakses pada tanggal 11 November 2019 diunduh dari http;//apjii.or.id/survei/2017

Azwar, S. (2009). Penyusunan skala psikologi edisi 1. Yogyakarta: Pustaka Belajar

Barseli, M., I. Ifdil, \& N. Nikmarijal. (2017). Konsep stres akademik siswa. 5(2005):143-148.

Cahyaningtyas, M. D. (2018). Hubungan frekuensi konsumsi minuman berkalori dengan status gizi pada siswa di SMA Negeri 5 Surakarta. Universitas Muhammadiyah Surakarta.

Data Pokok Pendidikan Dasar Dan Menengah (Dapodik). (2019). SMKN 2 JEMBER. Diakses pada 5 November 2019 diunduh https://dapo.dikdasmen.kemdikbud.go.i d/sekolah/7167C3AE09F6A5F0A8FC

Fitria, R.D. (2017). Pengaruh Pergaulan Teman Sebaya Terhadap Motivasi Belajar Siswa Kelas VIII Di SMP Negeri 28 Bandar Lampung Tahun Ajaran 2016/2017. Universitas Lampung

Griffiths, M. D. dan H. M. Pontes. (2016). Online Addictions: Conceptualizations . $1-14$.

Jap, T., S. Tiatri, E.S. Jaya, \& M.S. Suteja. (2013). The development of indonesian online game addiction questionnaire. $8(4): 4-8$.

Lee, Changho \& Ocktae, Kim. (2016). Predictors of online game addiction among korean adolescents. Addiction Research and Theory. 6359.

Masturoh, I. \& N. T. Anggita. (2018). Metode penelitian kesehatan. Bahan AJar Rekam Medis Dan Informasi Kesehatan. 1-307.

Masya, H. \& D. A. Candra. (2016). Faktor faktor yang mempengaruhi kecanduan game online. 03(1):153-169.

Notoatmodjo,S. (2012). Metodologi Penelitian Kesehatan. Jakarta: Rineka Cipta.

Nurdilla, N., Arneliwati, \& Elita, V. (2018). Hubungan kecanduan bermain game online dengan kualitas tidur remaja. JOM FKp. 5(2):120-126.

Nurazmi, A., Elita, V., \& Dewi, W.N. (2018). Hubungan kecanduan bermain game online terhadap regulasi emosi pada remaja. Fakultas Keperawatan. Universitas Riau.

Nursalam. (2017). Metodelogi Penelitian Ilmu Keperawatan: Pendekatan praktis edisi 4. Jakarta: Salemba Medika. 
Pang, Shirlene. (2017). Correlates of online game play motivations, social anxiety and psychological distress. Game Play, Social Anxiety and Distress. 46(11):443-446.

Piyeke, Phainel. Jhonly., \& Hendro, B, F. W. (2014). Hubungan tingkat stres dengan durasi waktu bermain game online pada remaja di manado. Jurnal Universitas Sam Ratulagi. (2)

Rahmadina, A., Ardiyanti, M. G. (2014). Hubungan Antara Kecanduan Game Online dengan Keterampilan Sosial pada Remaja. Universitas Gadjah Mada.

Rahmat, A. (2014). Hubungan kecanduan game online dengan keterampilan sosial remaja di 4 game centre di kecamatan klojen kota Malang. Skripsi Psikologi. 1-133.

Ridwan, S. (2015). Ketergantungan online game dan penanganannya. 1:84-92.

Safitri, E. (2019). Efektifitas Progressive Muscle Relaxation Dalam Mengatasi Stres Belajar Pada Peserta Didik Di Ma Alhikmah Bandar Lampung.

Sastroasmoro, S., \& Ismael, S. (2014). Dasar - dasar metodelogi penelitian klinis. Jakarta: Sagung Seto.

Septiana, P., \& Irwanto. (2018). Hubungan durasi tidur dengan kejadian obesitas pada anak usia $3-8$ tahun. Global Medical and Health Communication.6(47):63-67.

Suryanto, R. N. (2015). Dampak Positif dan negatif permainan game online dikalangan pelajar. Bina Widya Simpang Baru.

Susanto, R. E. (2010). Dampak Game Online pada Kalangan Mahasiswa. Universitas Sebelas Maret Surakarta.
Tan, J. B \& Yates, S. (2011). Academic Expectations as Sources of Stress in Asian Students. Social Psychology Education, Vol. 14, Hal. 389-407.

Taylor, Shawn., S.P. Angkoon., S. Sirirat., \& D. Woods. (2017). The theoretical underpinnings of internet addiction and its association with psychopathology in adolescence. International Journal of Adolescent Medicine and Health. 1-7.

World Health Organization (WHO). (2018). Gaming Disorder. Diunduh dari https://www.who.int/features/qa/gamin g-disorder/en/

Wulan, Dwi K. (2012). Faktor psikologis yang mempengaruhi perilaku merokok pada remaja. 2(3):504-511.

Wulandari, R. (2015). Fakultas psikologi universitas bina darma palembang 2015 . Fakultas Psikologi Universitas Bina Darma Palembang. 000:1-11. 